\title{
Response Macronutrient Content of Saline-Resistant Paddy to the Saline Source Distance
}

\author{
Aditya Nugraha Putra*, Martiana Adelyanti, Alberth Fernando Sitorus, \\ Qoid Luqmanul Hakim, Melati Julia Rahma, Istika Nita, Sudarto and Alia Fibrianingtyas \\ Veteran Malang Street No.1 Malang 65145, Indonesia Department of Soil Science, University of Brawijaya, \\ Indonesia.e-mail: aditya.n.putra@ub.ac.id
}

Received February 14, 2021; Revised April 22, 2021; Accepted 27 April 2021

\begin{abstract}
The impact of salinity on paddy production in Indonesia was pronounced with an average decline of $6.83 \%$ (20152019). Salinity interferes with macronutrient absorption into plants, causing stunted growth (salinity contributed to a $42 \%$ decrease in paddy production). One solution to solve the salinity problem in paddy is to use saline-resistant varieties. However, very few studies on macronutrient content analysis in resistant varieties responded to the salinity source's distance. Therefore, this research was conducted in the Jabon sub-district, Sidoarjo district, East Java, Indonesia, which aimed to study the macronutrient and plant growth responses to the saline source's distance. This research used two transects with a length of $2 \mathrm{~km}$ and $3.4 \mathrm{~km}$, respectively. The distance between the research location and the salinity source was $10.65 \mathrm{~km}$. The survey used a free grid to adjust the paddy field's location and the presence of resistant varieties. The results showed that the closer to the salinity source, the salinity indicators consisting of electrical conductivity, sodium adsorption ratio, exchangeable sodium percentage, and $\mathrm{pH}\left(\mathrm{H}_{2} \mathrm{O}\right)$ would increase. The increase in salinity then decreased macronutrients $(\mathrm{N}, \mathrm{P}$, and $\mathrm{K})$ in plants. However, tillers and leaves (length and number) were unaffected by high salinity levels in the soil.
\end{abstract}

Keywords: Macronutrient, paddy varieties, saline-resistant, salinity

\section{INTRODUCTION}

Salinity is a soil condition with dissolved salts accumulation on the soil surface, affecting agricultural production, biodiversity, and sustainable development. Saline soil is usually located on dry and semi-dry land, can be caused by evaporation, an intrusion of seawater, and its parent material (Gopalakrishnan and Kumar 2020). Saline soil is generally found in fluvio-marine and marine landforms and topographically tend to have a sloping slope (Hasmunir 2017). The formation process causes high salt deposits in the marine landform and fluvial-marine. Marine landform comes from seawater activities (Dewadaru and Saputro 2014) and the fluvio-marine landform is formed due to seawater activities and river activities (Wulan et al. 2016).

Saline soils are different from sodic and salinesodic soils. Saline soils have $\mathrm{pH}<8.5$ with electrical

J Trop Soils, Vol. 26, No. 1, 2021: 63-74

ISSN 0852-257X; E-ISSN 2086-6682 conductivity (EC) $>4 \mathrm{dS} \cdot \mathrm{m}^{-1}$, exchangeable sodium percentage (ESP) $<15 \%$ and sodium adsorption ratio $(\mathrm{SAR})<13$. While sodic soils have $\mathrm{EC}<4 \mathrm{dSm}^{-1}$, ESP $>15 \%$, and $\mathrm{pH}>8.5$. While, saline-sodic soils have $\mathrm{EC}>4 \mathrm{dSm}^{-1}, \mathrm{ESP}>15 \%, \mathrm{pH}>8.5$. Plant tolerance to salinity is very diverse. The level of salinity based on the EC can be divided into: nonsaline $\left(0-2 \mathrm{dSm}^{-1}\right)$, low $\left(2-4 \mathrm{dSm}^{-1}\right)$, medium (4 $\left.-8 \mathrm{dSm}^{-1}\right)$, high $\left(8-16 \mathrm{dSm}^{-1}\right)$, and very high $(>16$ $\mathrm{dSm}^{-1}$ ) (Follett et al. 1981; Sipayung 2003). High salinity levels increase the osmotic pressure and ionic toxicity while decreasing nutrient uptake $(\mathrm{N}, \mathrm{Ca}, \mathrm{K}$, $\mathrm{P}, \mathrm{Fe}, \mathrm{Zn}$ ) and cause oxidative stress (Shrivastava and Kumar 2015). The decrease in nutrient uptake resulted from a decrease in tillers, root length, plant height, shoot dry weight, roots, and whole plants. Salinity also affects photosynthesis, primarily through the reduction of leaf area, chlorophyll content, and stomatal conductance (Netondo et al. 2004; Shrivastava and Kumar 2015). This condition can reduce paddy productivity (Sitorus 2012).

The most commonly cultivated crop in saline soil was paddy. Paddy can adapt to almost any 
environment from lowland to highland, from tropical to subtropical, from wetland (swamp) to dry land, from fertile area to marginal area (salinity stress, high metal content, organic acids, drought). In Indonesia, paddy cultivation is carried out in various lands, including wetlands in lowland paddy fields, dry land, upland paddy fields, and peatlands (Utama 2015). Salinity can affect a plant's morphology, physiology, growth, and productivity (Akbarimoghaddam et al. 2011; Shrivastava and Kumar 2015).

Indonesia is the world's third-largest paddy producer after China and India (World Agricultural Production 2020). In 2019, Indonesia's paddy production reached 54.60 million tons with a planted area of 10.68 million ha (Central Statistics Agency $2020)$. Ironically, this production has grown significantly in the last five years (2015-2019) is $6.83 \%$ (Kementan 2019). Salinity contributes around $42 \%$ of the decline in national paddy production (Ahmed and Haider 2014).

One of the efforts to overcome the decline in paddy production due to salinity stress is by using saline-resistant varieties. Saline-resistant paddy varieties' growth is not disturbed on saline soil (Jalil et al. 2016). As a result, saline-resistant paddy varieties have grown and yielded more significantly than saline-sensitive paddy varieties (Habibi 2018). Therefore, it is crucial to study how nutrient content responds in resistant varieties to distance from the source of salinity. This analysis is essential given that the closer to the salinity source, the salinity indicator will also increase. In this study, researchers aimed to determine the response of saline-resistant varieties of paddy to salinity levels based on the distance of saline sources. This research is expected to support the government's food security program (NAWACITA) and Sustainable Development Goals.

\section{MATERIALS AND METHODS}

\section{Research Location}

The research activity was carried out in paddy fields in Jabon District, Sidoarjo Regency, East Java which is located in the lowlands, with coordinates of $112^{\circ} 70^{\prime} 36.17^{\prime \prime}-112^{\circ} 87^{\prime} 33.13^{\prime \prime}$ East Longitude and $7^{\circ} 49^{\prime} 40.01^{\prime \prime}-7^{\circ} 57^{\prime} 83.45^{\prime \prime}$ South Latitude (Figure 1). Jabon District is located in a lowland coastal area consisting of two alluvial and marine landscapes. Alluvial landforms with alluvial plains and marine sub-landforms with tidal plains sublandforms. The topography is influenced by fluviomarine sediments and alluvium material (Marsoedi et al. 1997). Types of soil owned are Typic Endoaquents, Typic Fluvaquents, Typic Hydraquents, and Typic Endoaquents (Soil Survey Staff 2014). The paddy field's total area was $1,883.86$ ha, or $23.05 \%$ (of the total area from the Jabon sub-district).

The research location was determined based on the initial salinity analysis with the EC value of

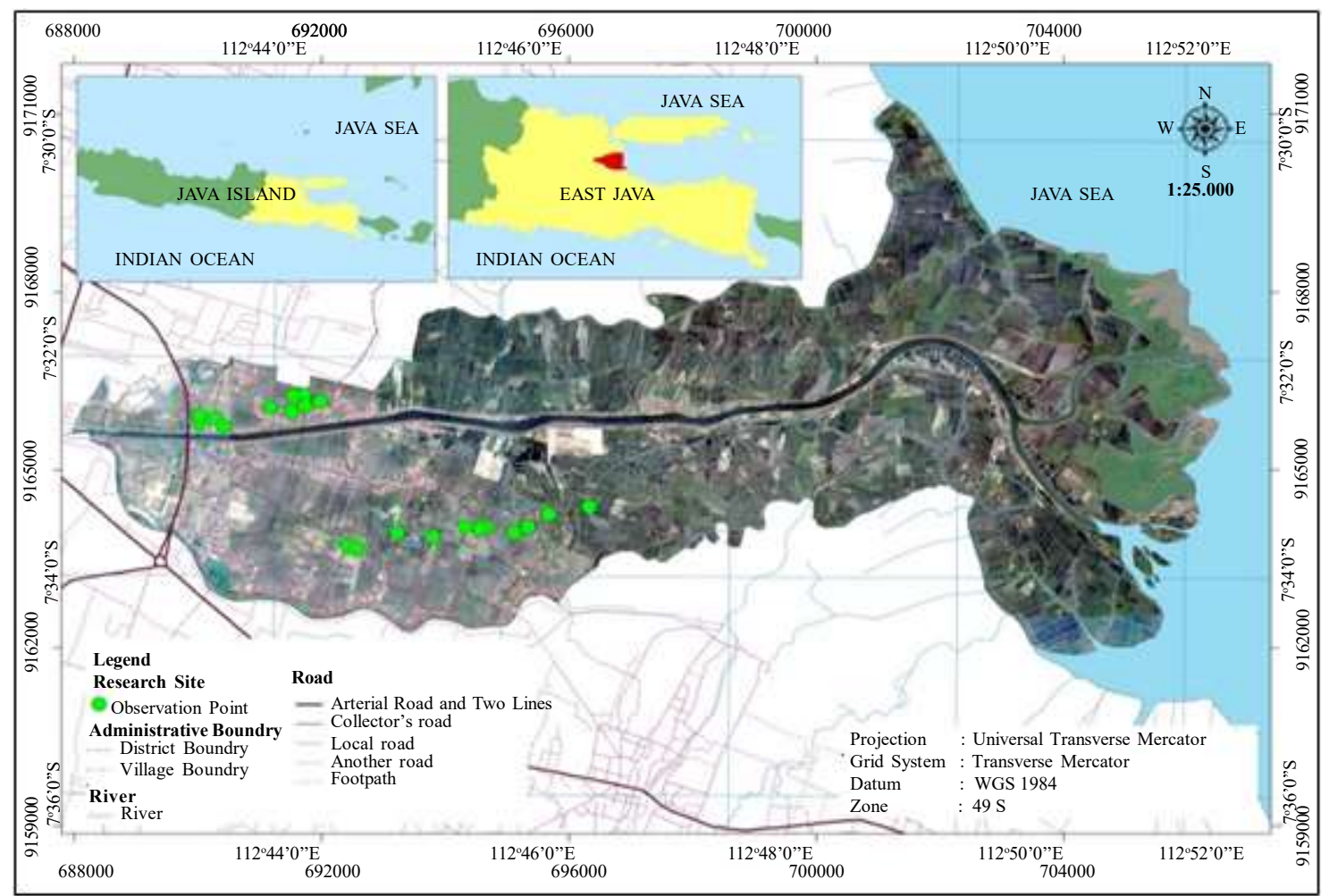

Figure 1. Distribution of research observation points (modification from Putra 2021) 
$9.6 \mathrm{dSm}^{-1}$ and Na-ex was $1.8 \mathrm{cmol} \mathrm{kg}^{-1}$. This research was located on two transects, the transect one length was $\pm 2 \mathrm{~km}$ with the observation point interval 316 $814 \mathrm{~m}$, and transect two was $\pm 3.4 \mathrm{~km}$ with the observation point interval distance of 104-718 m. Each transect has ten observation points. The distance between the research location and the salinity source was $10.65 \mathrm{~km}$ and determined by the free grid (Rayes 2007). The distance between the saline source and observation point uses the ArcGIS 10.3 application with the line measurement tools. The paddy crops in the research area are saline-resistant varieties that have been registered in the Agency for Agricultural Research and Development.

\section{Soil and Plant Sampling}

Soil and plant samples were taken at each observation point at different distances from the saline source and composite sampling (Pennock and Yates 2006). The sampling of paddy plants was carried out by taking part in the leaves (Setiawan and Herdianto 2018). Soil samples taken were the layer of paddy root areas, taken from a depth of 0 $20 \mathrm{~cm}$ (Vadas et al. 2006).

\section{Soil and Plant Analysis}

Biomass macronutrient analysis was conducted by Nitrogen (Total-N) (Bremner and Mulvaney 1982), Phosphorus (Total-P) (Bray and Kurtz, 1945), Potassium (Total-K) (AOAC 2002). Soil salinity analyses are divided into ESP (Gupta and Sharma 1990), $\mathrm{pH} \mathrm{H}_{2} \mathrm{O}$ (Amran et al. 2015), EC (Rhoades et al. 1989), and SAR (Robbins 1984).

\section{Statistical Analysis}

Statistical analysis was carried out by data normality test, correlation test, and regression test. The normality test was carried out by Genstat 10.4 with the Shapiro-Wilk method (Royston 1992) to determine data distribution. The average data ( $>$ 0.05 ) will be continued to the correlation test with $R$ software. The correlation coefficient ( $r$ ) was compared to the r-table. A regression test is then followed by correlating data (Putra and Nita 2020).

\section{RESULTS AND DISCUSSION}

\section{Soil Salinity, Macronutrients, and Plant Growth Indicator Analysis}

The analysis results show that all salinity indicators fall into the criteria for saline soil. The EC value ranges from 7.35 to $8 \mathrm{dS} \mathrm{m}^{-1}$, where the closer to the source of salinity, the value increases. $\mathrm{pH} \mathrm{H}_{2} \mathrm{O}$ also has the same trend as EC, with a value range of 5.59 to 5.83. The range of ESP values fluctuates concerning the copy source's distance, while the SAR ranges from 0.26 to 0.53 (the value gets higher when it approaches the salinity source) (Table 1 ).

The number of tillers, length, and the number of leaves of paddy plants in the saline area was found that at the farthest distance of $13.5 \mathrm{~km}$ from the salinity source, the number of tillers was 45.7 , the length of the crops was $96.7 \mathrm{~cm}$, and the number of leaves was 209.5. Whereas at the closest distance of $10.3 \mathrm{~km}$ from the salinity source, the number of tillers value was 25.5 , the length of the plant was $80.9 \mathrm{~cm}$, and the number of leaves was 87.8 . The distance that has the highest number of tillers was $13.5 \mathrm{~km}$ at 45.7 , and the lowest was at $10.3 \mathrm{~km}$ at 25.5. While, the highest plant length was $10.64 \mathrm{~cm}$ at $102.8 \mathrm{~cm}$, and the lowest was at $13.2 \mathrm{~km}$ at 57.8 $\mathrm{cm}$. Moreover, the highest number of leaves was $13.5 \mathrm{~km}$ at 209.5 , and the lowest was $13.2 \mathrm{~km}$ at 79.5. The differences in crop age and paddy varieties affected the yields. The varieties used at all observation points were Ciherang, Inpari 32, and Inpari 42 varieties, where the varieties were different for each observation point. In terms of plant age, according to the statement by Banyo et al. (2013) that, in the vegetative phase, plants with a longer planting age caused a higher chlorophyll concentration than plants with a faster vegetative phase. According to Pratama and Nikmati (2015), plant age affects chlorophyll's value in leaves. Research by Mardiansyah (2018) stated that the Ciherang variety has moderate salinity tolerant characters. The Inpari 32 variety is an inbred variety from the selection results of the Ciherang variety, and Inpari 42 is a salinity tolerant variety (Agricultural Research and Development Agency 2019). Moreover, Irman et al. (2017) mentioned the salinity did not affect plant chlorophyll levels.

The closer the distance to the saline source was, the value of $\mathrm{N}, \mathrm{P}$, and $\mathrm{K}$ in the biomass decreased. For example, the soil $\mathrm{N}$ value at $13.5 \mathrm{~km}$ farthest from the salinity source was $0.45 \%$, P was $28.43 \mathrm{mg}$ $100 \mathrm{~g}^{-1}$, and $\mathrm{K}$ was $41.7 \mathrm{mg} 100 \mathrm{~g}^{-1}$. Whereas at the distance of $10.3 \mathrm{~km}$ closest to the salinity source, $\mathrm{N}$ values were $0.3 \%, \mathrm{P}$ was $18.46 \mathrm{mg} 100 \mathrm{~g}^{-1}$, and $\mathrm{K}$

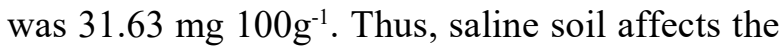
availability of nutrients in the biomass (Soussi 1998).

\section{Salinity Indicator Content Analysis Based on Salinity Source Distance}

The salinity indicators consisting of $\mathrm{EC}, \mathrm{pH}$ $\mathrm{H}_{2} \mathrm{O}$, ESP, and SAR all show an increase in each indicator's value when the distance to the source of 
Table 1. The analysis results of Salinity, Macronutrient, and Plant Growth Indicator.

\begin{tabular}{|c|c|c|c|c|c|c|c|c|c|c|}
\hline \multirow{2}{*}{$\begin{array}{c}\text { Distance } \\
(\mathrm{km})\end{array}$} & \multicolumn{4}{|c|}{ Salinity Indicator (Putra 2021) } & \multirow[t]{2}{*}{ Tillers } & \multicolumn{2}{|c|}{ Leaves } & \multirow[t]{2}{*}{$\mathrm{N}$} & \multirow{2}{*}{$\frac{P}{--\%--}$} & \multirow[t]{2}{*}{ K } \\
\hline & $\begin{array}{c}\mathrm{EC} \\
\left(\mathrm{dS} \mathrm{m} \mathrm{m}^{-1}\right)\end{array}$ & $\begin{array}{c}\mathrm{pH} \\
\mathrm{H}_{2} \mathrm{O}\end{array}$ & $\begin{array}{l}\text { ESP } \\
(\%)\end{array}$ & SAR & & $\begin{array}{l}\text { Length } \\
(\mathrm{cm})\end{array}$ & Amount & & & \\
\hline 13.40 & 7.35 & 5.59 & 7.38 & 0.26 & 35.30 & 96.80 & 127.60 & 1.39 & 0.59 & 5.11 \\
\hline 12.90 & 7.39 & 5.64 & 8.34 & 0.31 & 27.10 & 67.20 & 103.40 & 1.31 & 0.48 & 3.97 \\
\hline 13.20 & 7.54 & 5.62 & 8.99 & 0.35 & 28.20 & 57.80 & 79.50 & 1.31 & 0.48 & 4.04 \\
\hline 13.00 & 7.65 & 5.69 & 10.73 & 0.48 & 32.70 & 64.80 & 106.00 & 1.34 & 0.53 & 4.49 \\
\hline 12.00 & 7.58 & 5.72 & 9.72 & 0.40 & 34.10 & 64.90 & 125.20 & 1.33 & 0.51 & 4.31 \\
\hline 11.69 & 7.72 & 5.65 & 11.05 & 0.53 & 25.90 & 79.70 & 114.50 & 1.26 & 0.41 & 3.30 \\
\hline 11.46 & 7.61 & 5.74 & 9.59 & 0.41 & 34.70 & 86.75 & 158.80 & 1.30 & 0.47 & 3.87 \\
\hline 11.61 & 7.75 & 5.82 & 11.04 & 0.55 & 34.50 & 92.70 & 148.00 & 1.27 & 0.42 & 3.45 \\
\hline 11.43 & 7.65 & 5.90 & 9.80 & 0.45 & 37.50 & 88.70 & 123.80 & 1.26 & 0.42 & 3.41 \\
\hline 11.20 & 7.84 & 5.94 & 10.14 & 0.51 & 38.10 & 85.30 & 174.20 & 1.24 & 0.38 & 3.06 \\
\hline 13.50 & 7.40 & 5.52 & 6.30 & 0.22 & 45.70 & 96.70 & 209.50 & 1.38 & 0.58 & 4.97 \\
\hline 13.43 & 7.45 & 5.54 & 7.34 & 0.28 & 30.10 & 67.50 & 163.10 & 1.36 & 0.55 & 4.73 \\
\hline 12.76 & 7.62 & 5.62 & 8.05 & 0.33 & 32.50 & 72.90 & 115.80 & 1.37 & 0.57 & 4.84 \\
\hline 12.19 & 7.73 & 5.70 & 9.93 & 0.44 & 42.30 & 101.60 & 175.50 & 1.29 & 0.46 & 3.79 \\
\hline 11.65 & 7.65 & 5.76 & 9.87 & 0.42 & 32.70 & 82.80 & 121.50 & 1.32 & 0.50 & 4.17 \\
\hline 11.42 & 7.79 & 5.59 & 11.13 & 0.55 & 29.00 & 92.50 & 116.40 & 1.28 & 0.44 & 3.62 \\
\hline 11.31 & 7.68 & 5.64 & 9.74 & 0.43 & 26.10 & 85.10 & 102.30 & 1.29 & 0.45 & 3.74 \\
\hline 10.87 & 7.83 & 5.70 & 11.13 & 0.57 & 39.10 & 91.60 & 137.10 & 1.26 & 0.41 & 3.30 \\
\hline 10.64 & 7.73 & 5.80 & 9.94 & 0.47 & 35.00 & 102.80 & 156.90 & 1.27 & 0.42 & 3.42 \\
\hline 10.30 & 7.92 & 5.83 & 10.25 & 0.53 & 25.50 & 80.90 & 87.80 & 1.25 & 0.39 & 3.15 \\
\hline
\end{tabular}

the saline gets closer (Figure 2). The EC value at all observation points increased about $7.4 \mathrm{dSm}^{-1}$ at a distance of $13.5 \mathrm{~km}$ and $7.9 \mathrm{dSm}^{-1}$ at $10.5 \mathrm{~km}$. The same increasing pattern also occurred in $\mathrm{pH}$ $\mathrm{H}_{2} \mathrm{O}$ and SAR. Soil $\mathrm{pH} \mathrm{H}_{2} \mathrm{O}$ increased from about 5.5 to almost 6.0 as the closest distance from the saline source. Other indicators, namely SAR, increased from $0.2 \%$ to $0.6 \%$, and ESP increased from 6 to around 10. The EC had a normality test value of $0.63 \mathrm{dS} \mathrm{m}^{-1}$ when the $\mathrm{pH} \mathrm{H}_{2} \mathrm{O}$ was 0.73 . ESP and SAR have a normality test value of $0.25 \%$ and 0.3 , respectively. All parameters data can be expected because the values are more than 0.05 . The correlation test showed that all parameters of the saline indicator were correlated with the distance of the saline source. Electrical conductivity has the highest correlation with -0.83 , followed by SAR, ESP, and $\mathrm{pH} \mathrm{H}_{2} \mathrm{O}$ to distance (r-table was 0.36 ).

The regression analysis showed that the salinity distance influenced the soil salinity indicator. Electrical conductivity has the highest coefficient determination $\left(\mathrm{R}^{2}\right)$ for about 0.73 , and the other factors were less than 0.7. According to Kolinug (2014), the closest land to the sea has a higher salinity value because seawater supply is more in areas directly adjacent to the sea.

\section{Nitrogen, Phosphorus, and Potassium Biomass Content}

Macronutrient (Total-N, Total-P, and Total-K) content decreased when the salinity source's distance is further away (Figure 3). The Total-N value in all observation points decreased from about $1.38 \%$ at a distance of $13.5 \mathrm{~km}$ to $1.25 \%$ at 10.5 $\mathrm{km}$. The same pattern also occurred in Total-P and Total-K. Phosphorus decreased from about $0.58 \%$ to $0.39 \%$ when the saline source's distance got closer. Other indicators, $\mathrm{K}$, decreased from $4.97 \%$ to $3.15 \%$ at the same distance. The data were normally distributed with $\mathrm{N}, \mathrm{P}$, and $\mathrm{K}$ 's respective values of $0.34,0.60$, and 0.60 (more than the $\mathrm{p}$ value $(0,05))$. The regression analysis between the macronutrients $(\mathrm{N}, \mathrm{P}$, and $\mathrm{K})$ and the saline source show the N, P, K contents were getting lower when approaching the salinity source.

The low macronutrient contents were due to the low level of saline soil fertility and nutrient deficiencies elements (Dewi and Setiawati 2018). 

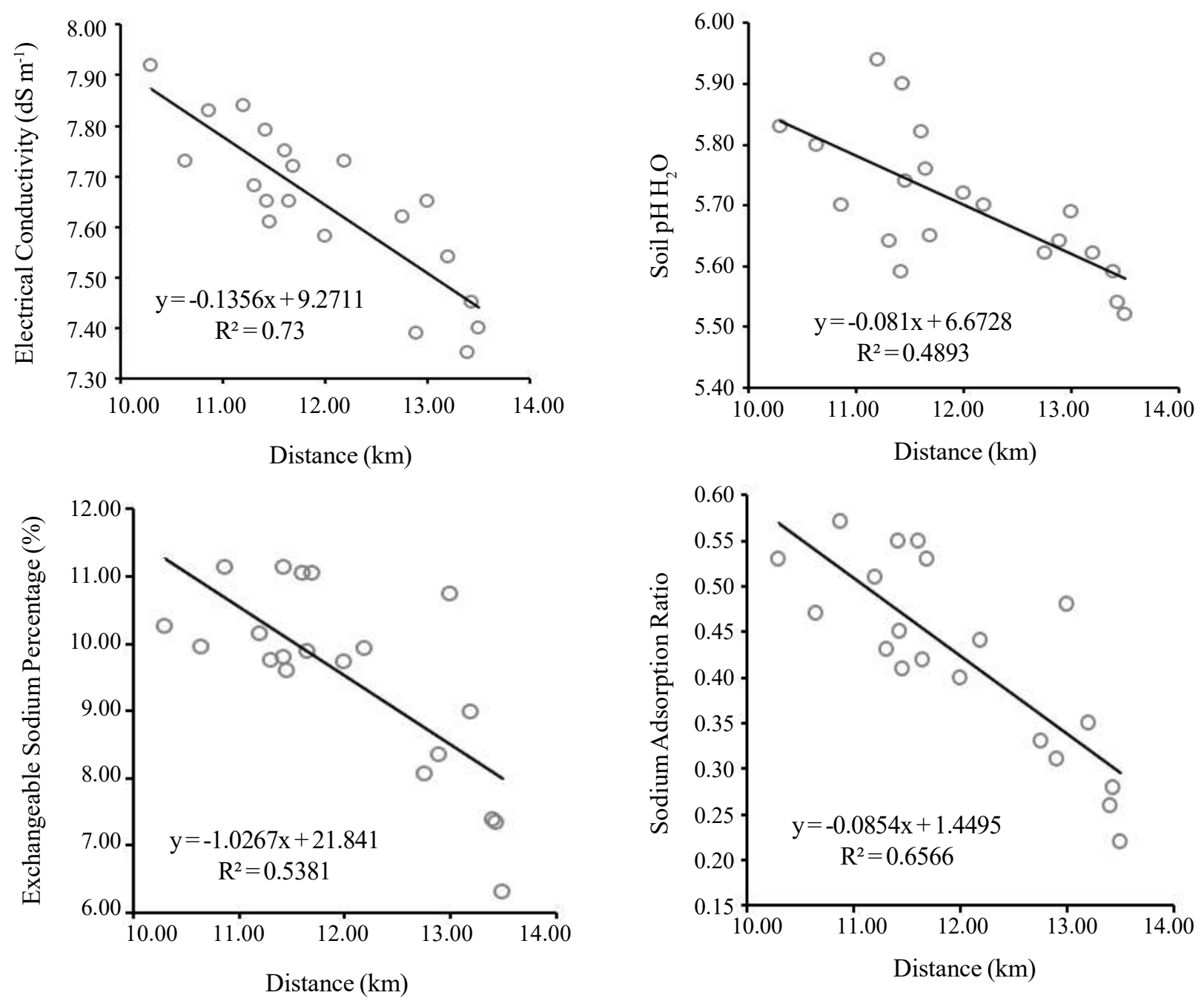

Figure 2. A correlation analysis show the increasing value of the salinity Indicators with the closer salinity source.

A large number of $\mathrm{Na}$ ions in the soil causes a decrease in the Ca-exc, Mg-exc, and K-exc ions (Muliawan et al. 2016). In addition, saline soil contains high salt, which causes the absorption of nutrients and water into the plants to be inhibited (Nasrudin and Kurniasih 2018). Research Kolinug (2014), the closest land to the sea has a higher salinity value because the supply of seawater is more in areas directly adjacent to the coast.

\section{Salinity Effect on the Macronutrient Content}

In general, all macronutrients have a close relationship with electrical conductivity. This result was illustrated from the adjacent data distribution on the line with a negative $y$ value. The relationship between EC and ${ }_{\text {Total }}-\mathrm{N}$ in the form of linear lines is $y=-0.2361 x+3.1089\left(R^{2}=0.67\right)$. The ${ }_{\text {Total }}-P$ content in the soil and EC also has a close relationship and negative correlation. Intended with the values $y=-$ $0.335 x+3.0337$ and $R^{2}=0.6603$. The relationship indicates that the higher the EC, the soil's P content will decrease (Figure 4).

The value of $\mathrm{K}$ content also negatively affects $\mathrm{EC}$, meaning that it is inversely proportional. This is indicated by the value $\mathrm{y}=-3.2652 \mathrm{x}+28.896$ and $\mathrm{R}^{2}$ $=0.66$. Electrical conductivity is the ability to conduct electrical currents affected by dissolved salts that can be ionized. Electrical conductivity is affected by ions, valence, and concentration. Electrical conductivity is related to the movement of ions. The easier the ions move, the larger the EC (Muliawan et al. 2016). According to (Sipayung 2003), plants can be disturbed by the EC value of more than 2 mmhos. The higher the EC value, the more disturbed the plant growth. Some problems are caused, so soil copy is rarely used for plant cultivation, including low osmotic pressure. The adverse influence of salinity on plants is related to the high osmotic pressure of water, an imbalance between ions $\mathrm{Na}, \mathrm{K}, \mathrm{Ca}, \mathrm{Mg}$ related to decreased 

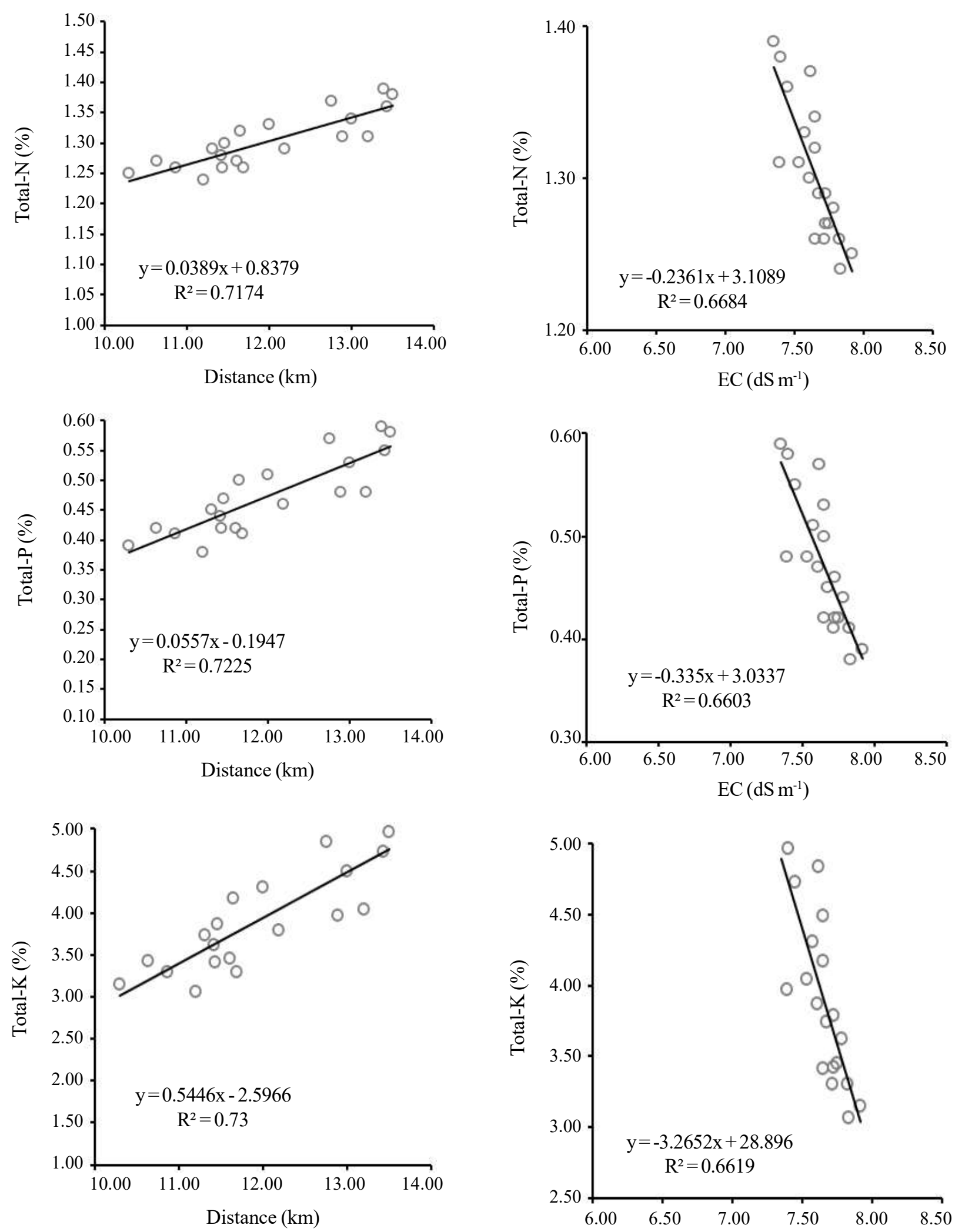

Figure 3. A correlation between Macronutrient content (a) Total-N (\%), (b) Total-P (\%), (c) Total-K (\%), and the distance from the salinity source.

absorption of $\mathrm{N}$ and $\mathrm{P}$. Concentrations of $\mathrm{Na} / \mathrm{Ca}^{2} \mathrm{Z}$ or extreme $\mathrm{Naz} / \mathrm{Kz}$ can interfere with the absorption of $\mathrm{Ca}$ and $\mathrm{K}$ ions (Wahyuningsih and Kristiono 2017).

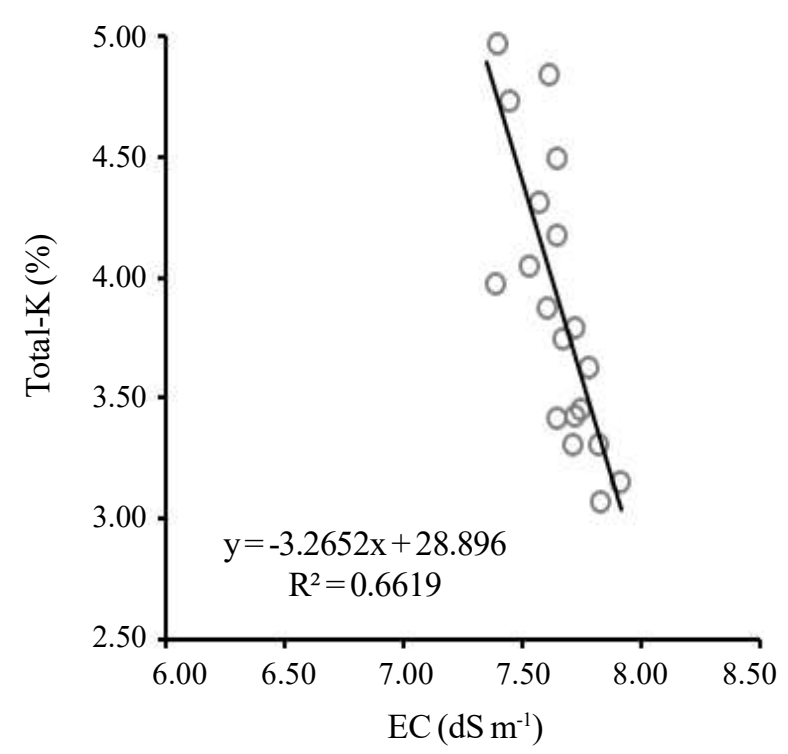

Figure 4. A Regression Analysis between electrical conductivity (EC) and macronutrients

Similarly, all macronutrients N, P, and K have a close relationship with inversely proportional with $\mathrm{pH}_{2} \mathrm{O}$. For example, the relationship between $\mathrm{pH}$ $\mathrm{H}_{2} \mathrm{O}$ and soil Total- $\mathrm{N}$ in linear lines was $\mathrm{y}=-0.2818 \mathrm{x}$ 
+2.9101 , with $\mathrm{x}$ is $\mathrm{pH} \mathrm{H}_{2} \mathrm{O}$ and $\mathrm{y}$ is soil Total- $\mathrm{N}\left(\mathrm{R}^{2}\right.$ $=0.51$ ) Figure 5 .

Phosphorus total content value also has a negative effect with $\mathrm{pH} \mathrm{H}_{2} \mathrm{O}$, meaning it is inversely proportional. This is indicated by the values $\mathrm{y}=$ $0.396 \mathrm{x}+2.7306$ and $\mathrm{R}^{2}=0.49$. If $\mathrm{pH} \mathrm{H}_{2} \mathrm{O}$ has a higher value, then total-P will decrease. The content
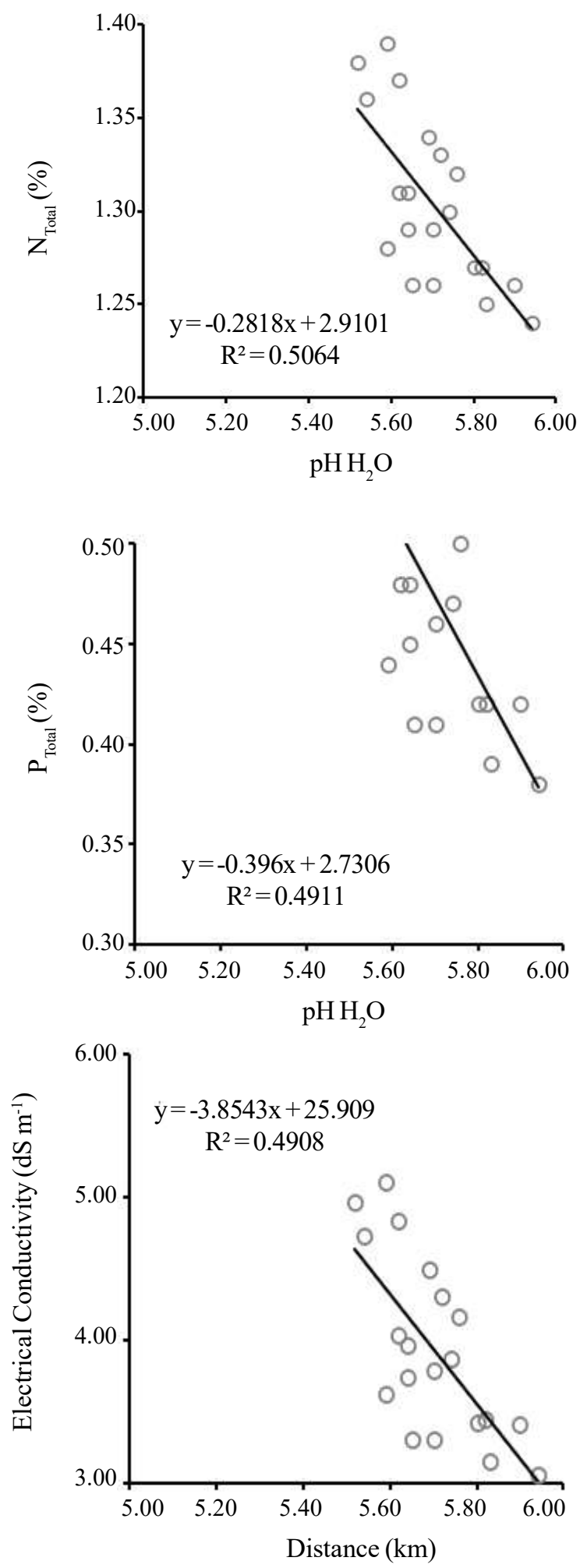

Figure 5. A regression analysis between $\mathrm{pH} \mathrm{H}_{2} \mathrm{O}$ and macronutrients. of $\mathrm{K}$ in the soil and $\mathrm{pH}_{2} \mathrm{O}$ also has a closely related but inversely proportional. Intended with the values $\mathrm{y}=-3.8543 \mathrm{x}+25,909$ and $\mathrm{R}^{2}=0.49$ with ' $\mathrm{X}$ was $\mathrm{pH} \mathrm{H}_{2} \mathrm{O}$, and ' $\mathrm{y}$ ' was total-K.

The influence of water sources containing high salts causes a pH increase (Awatt Project 2009). Soil $\mathrm{pH}$ is related to the availability of nutrients in the soil. Soil $\mathrm{pH}$ is low (acidic), the soil is dominated by positive content, while the soil $\mathrm{pH}$ is high (alkaline soil), the soil is dominated by negative content. The high salt content in saline soil causes soil structure damage, so its aeration and permeability become very low. In addition, a large number of $\mathrm{Na}$ ions in the soil causes reduced ions of $\mathrm{Ca}, \mathrm{Mg}$, and $\mathrm{K}$ that can be exchanged so that the availability of nutrients for plants decreases (Hardjowigeno 2010).

The relationship between ESP and all macronutrients $\mathrm{N}, \mathrm{P}$, and $\mathrm{K}$ is closely related but negative. The correlation between ESP and the Total-N content value in the soil is indicated by the value $y=-0.026 x+1.5518$ and $R^{2}=0.6307$ with $x$ was ESP and y is Total-N.

The relationship between ESP and total-P in the ground is a linear line with $y=-0.0365 x+0.8208$ where $\mathrm{x}$ is ESP and $\mathrm{y}$ is Total-P $\left(\mathrm{R}^{2}=0.61\right)$. The linkage shows a negative tendency that the higher ESP makes Total-P has a lower value. The soil Total$\mathrm{K}$ content in the soil and ESP also has a closely related but inversely proportional. Indicated by the value $y=$ $-0.3573 x+7.3398$ and $R^{2}=0.6157$ (Figure 6).

The exchangeable sodium percentage is a Naex salt percentage. Exchangeable sodium percentage is formulated as the Na rate of Cation Exchange Capacity x 100\% (Awatt Project 2009). However, there are also direct effects of ESP on soil solution chemistry, a necessary result of the chemical equilibrium developed between the exchangeable and solution ions. One explanation is that low plant $\mathrm{P}$ and $\mathrm{K}$ concentrations result from poor soil structure, which impedes root growth, increases waterlogging, and restricts access to soil water and nutrients. An alternative explanation is that $\mathrm{P}$ and $\mathrm{K}$ uptake are directly affected by the chemical composition of the soil solution that is developed in response to the high ESP, for example, by competition between ions for uptake (Dodd et al. 2010).

All macronutrient Total-N, Total-P, and TotalK have a close relationship with SAR but inversely proportional (Figure 7). The relationship between SAR and $N$ total land in linear lines is $y=-0.3693 x$ +1.4608 , with $\mathrm{x}$ is SAR and $\mathrm{y}$ is Total-N and $\left(\mathrm{R}^{2}=\right.$ 0.72 ). The relationship shows a negative tendency that the higher the SAR, the Total-N will be decreased. 
The sodium adsorption ratio is the ratio between the levels of $\mathrm{Na}$ to the amount of $\mathrm{Ca}$ and $\mathrm{Mg}$, expressed in SAR $=\left[\mathrm{Na}^{+}\right] /\left(\left[\mathrm{Ca}^{2+}+\mathrm{Mg}^{2+} / 2\right]^{1 / 2}\right.$ (Awatt Project 2009). Robbins (1984) concluded that higher $\mathrm{K}$ was held in the soil while $\mathrm{Na}$ leached down,
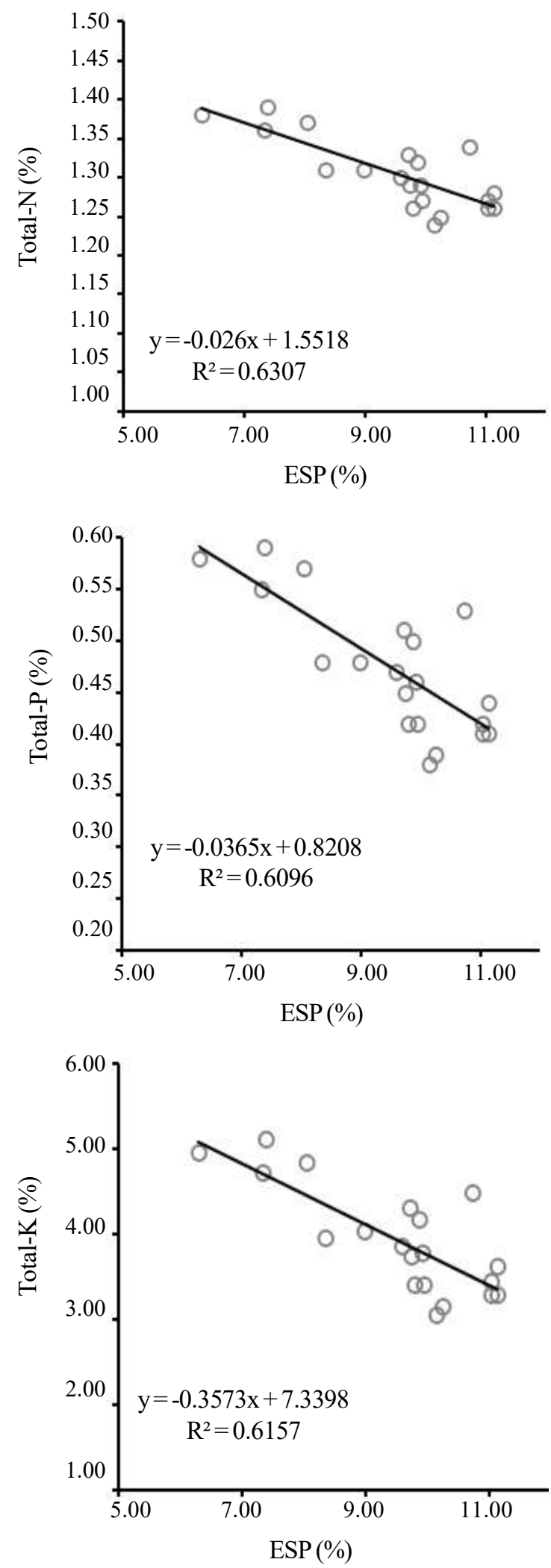

Figure 6. A regression analysis between ESP and macronutrients. reducing SAR and ESP. Potassium competes with other cations such as $\mathrm{Ca}$ and $\mathrm{Mg}$ for retention on soil exchange sites, and high $\mathrm{K}$ levels may lead to increased leaching of $\mathrm{Na}$ and associated anions such as $\mathrm{SO}_{4}^{-}$and $\mathrm{Cl}^{-}$. A slight increase in $\mathrm{Ca}$ was observed
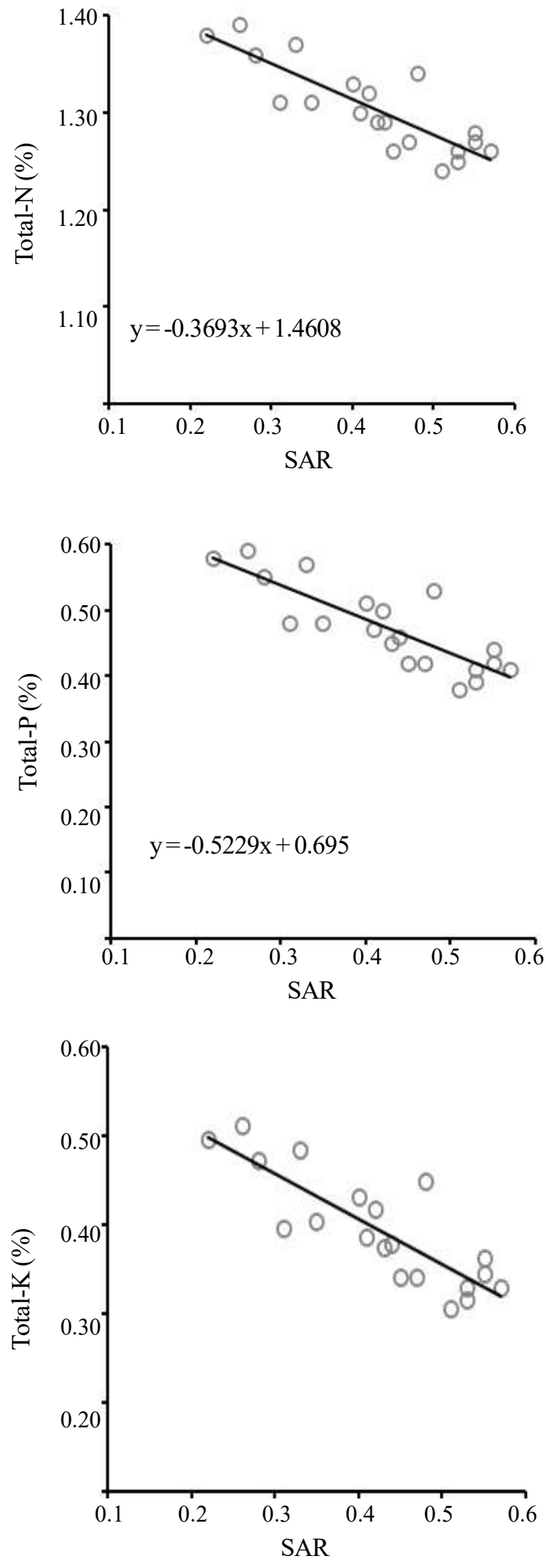

Figure 7. A regression analysis between SAR and macronutrients. 
with $\mathrm{K}$ under both irrigations. Hence, the $\mathrm{Ca}$ : $\mathrm{K}$ ratio slightly decreased with $\mathrm{K}$ and increased with $\mathrm{P}$. The leaching of $\mathrm{Mg}$ increased with $\mathrm{P}$ and $\mathrm{K}$ treatments alone or combined with saline irrigation. The $\mathrm{Ca}$ and $\mathrm{Mg}$ in leachates suggested that $\mathrm{K}$ application resulted in more $\mathrm{Ca}$ than $\mathrm{Mg}$ leaching (Morton et al. 2004). The $\mathrm{Na}, \mathrm{Ca}$ and $\mathrm{Mg}$ were responsible for the variations in SAR of the leachates. Also, saline water in saline-sodic soil increased soil SAR due to $\mathrm{Na}$ 's leaching from surface layers (Akhtar et al. 2003).

\section{DISCUSSION}

Soil salinity variability is influenced by the influence of the source of soil salinity, namely seawater in coastal areas. Thus, the observation points from the farthest distance to the closest to the salinity source illustrate the variability of low to high salinity. The landform in Jabon District is fluviomarine, formed by a mixture of river sediment (alluvium) and sea sediment (marine), which was previously an ocean that has become land area still contains salt deposits in the lower underground. The area near the coast is still affected by tides. Thus the salt content in the area is higher than in areas further from the coast. Marwanto, Rachman, and Erfandi (2009) explain that the closer to the saline source (beach), the more salinity increases. Increased salinity in paddy fields occurs near the coast or paddy fields with water channels directly connected to seawater. The increase in salt concentration in the soil is an environmental stress factor that many rice fields suffer, especially those close to the coast (Rachman et al. 2018).

Salinity significantly affects the N, P, and K contents. The higher the salinity value, the lower the plant N, P, and $\mathrm{K}$ values. This result was due to the growing substrate's reduced water potential (growing media) and the increased absorption of $\mathrm{Na}, \mathrm{Cl}$, or both. In addition, high salinity levels (the number of $\mathrm{Na}$ ions) cause a reduction in the $\mathrm{Ca}-\mathrm{exc}, \mathrm{Mg}$-exc, and $\mathrm{K}$-exc ions, which means a decrease in soil nutrients uptake (Suhartini and Zulchi 2018).

Saline soil affects the absorption of N, P, and K nutrients in plants. The specific effect of soil saline on plant metabolism, especially on leaf aging, is associated with the accumulation of toxic $\mathrm{Na}^{+}$and $\mathrm{Cl}^{-}$ions and decreased $\mathrm{K}^{+}$. Salinity associated with excess $\mathrm{NaCl}$ affects plant growth and yield by suppressing water and mineral absorption and normal metabolism (Al-Karaki 2000).

According to (Sipayung 2003), salinity inhibits the growth of roots, stems, and leaf area, and there is a metabolic imbalance caused by ionic poisoning
$\left(\mathrm{Na}^{+}\right.$) and nutrient deficiency (N, $\mathrm{P}$, and $\left.\mathrm{K}\right)$. The $\mathrm{P}$ concentration in agronomic plants grown in the field decreases with increasing salinity. Salinity decreases the $P$ concentration in plant tissue; elsewhere, salinity increases $\mathrm{P}$ or does not affect it. It is not surprising that differences between studies occur because $P$ concentrations vary widely in different experiments, and other nutrient interactions can coincide (Grattan and Grieve1999). Several studies have shown that the concentration of $\mathrm{K}^{+}$in plant tissue decreases with the increasing salinity of $\mathrm{NaCl}$. The reduction of $\mathrm{K}^{+}$uptake in plants by $\mathrm{Na}^{+}$is a competitive process. Salinity decreases the $\mathrm{K}^{+}$accumulation in leaves (Machanda and Garg 2008). The destructive effect of salinity on plants is related to the high osmotic pressure of water, an imbalance between $\mathrm{Na}$ and $\mathrm{K}, \mathrm{Ca}, \mathrm{Mg}$ ions, and the $\mathrm{N}$ and $\mathrm{P}$ uptake.

Salinity increases as the land become closer to the source of salinity. This increase has an effect on barriers to nutrient uptake by plants. Increased salinity in paddy fields occurs near the coast or paddy fields with water channels directly connected to seawater. The higher the $\mathrm{NaCl}$ concentration in the soil, the higher the osmotic pressure and the soil's EC (Sipayung 2003). The harmful effects of highsalt water affect plant height, fresh weight, and leaf area. In addition, the absorption of saltwater by plant roots can cause a decrease in water content in plant tissues, which will affect metabolic processes in cells (Salama et al. 2012).

The number of leaves, the number of tillers, and leaf length have a normality test at a rate of $0.61,0.60,0.51$, and 0.46 . The correlation between paddy performance and the saline indicator is very low, and the r-value is smaller than the r-table. The value of the r-table is 0.4438 . The correlation values (r-value) between tillers and salinity indicators $(\mathrm{pH}$ $\mathrm{H}_{2} \mathrm{O}, \mathrm{EC}, \mathrm{ESP}, \mathrm{SAR}$ ) are only $0.13,-0.08,-0.20$, 0.14 , respectively. The correlation values between the length of leaves and salinity indicator are only $0.21,0.27,0.13,0.24$, respectively. The correlation values between amounts of leaves and salinity indicator are only $0.01,-0.12,-0.31,-0.20$, respectively. So, it can be interpreted that the saline indicator does not influence paddy performance. The paddy's growth performance (tiller, leaves amount, and leaves length) was stuck because of the paddy plant's lack of macronutrients. Macronutrients as an intake will be distributed to other organs like a stem, tiller, leaves, and others. Nitrogen is the essential intake for accelerating the paddy plant's growth (Leghari et al. 2016). However, the result was the opposite because various paddy plant varieties were resistant to salinity, such as Ciherang, Inpari 32, and Inpari 42. It can override the impact 
of salinity that degrade the macronutrient of paddy plants. Moreover, this condition is supported by the research of Jalil et al. (2016). Salinity had no significant effect on the number of leaves, plant length, and tillers' number on salinity-resistant varieties.

The closest distance of saline source increases the salinity that affects the macronutrient degradation of plants, and the opposite does. However, in this research, distance from the saline source has no impact on tillers. The correlation value is shallow, only 0.12 ; it is smaller than the r-table. So, the saline source does not have an impact on the tillers of the paddy plant. Although salinity impacts macronutrients like $\mathrm{N}$ were lacked, according to Leghari et al. (2016), it will degrade the plant's growth performance, just like the tillers. Then it will not be applicable if the paddy plant was resistant to variety. The variety used in this research are Ciherang, Inpari 32, and Inpari 42, all of them, based on Suhartini and Zulchi (2018) statement, are resistant varieties in salinity conditions. Therefore, salinity has no impact on the tiller because of resistant variety.

In this study, the results showed that plant performance was not affected by salinity levels. This result was evidenced by the correlation between plant performance and the salinity indicator, which has a low value. The use of saline-resistant varieties means that plant performance is not affected by differences in salinity levels. So, it can be said that the use of saline-resistant varieties is efficient in overcoming salinity problems. Therefore, the use of tolerant varieties is the most effective way to exploit the potential of saline soil to increase national paddy production (Jalil et al. 2016).

According to Firmansyah et al. (2016), salineresistant paddy plants have one or more prevention toxicity mechanisms. Adaptive paddy mechanism to salinity is synthesized secondary metabolites for osmotic adjustment — organic metabolite known as osmoregulators because of its characteristics. The osmotic adjustment refers to the accumulation of dissolved substances in cells as a plant response to decrease potential water. It can maintain osmotic potential and cell turgor pressure. So, this mechanism can maintain the rate of water and nutrient absorption in osmotic conditions. Moreover, plasmolysis in plant cells can be prevented, so organic metabolite is known as osmoprotectants.

\section{CONCLUSIONS}

The salinity distance affects the level of soil salinity in the Jabon sub-district, Sidoarjo District, which $\mathrm{EC}, \mathrm{pH}_{2} \mathrm{O}$, ESP, and SAR will increase when the salinity source's distance gets closer. The increase in salinity levels causes the plant biomass, macronutrient content (Total-N, Total-P, and Total$\mathrm{K})$ reduced. So, it can be explained that the saline source's distance affects the decrease in macronutrients. Although the macronutrient content decreased, the use of resistant varieties was proven to withstand salinity stress. In addition, tillers and leaves (length and number) were unaffected by high salinity levels in the soil.

\section{ACKNOWLEDGMENT}

The author would like to thank the University of Brawijaya for the Research Grant in 2020.

\section{REFERENCES}

Agricultural Research and Development Agency. 2019. Indonesian Agency for Agricultural Research and Development Ministry of Agriculture. URL http:// en.litbang.pertanian.go.id/.

Ahmed MF and MZ Haider. 2014. Impact of salinity on rice production in the south-west region of Bangladesh. Environ Sci Indian J 9: 135-141.

Akbarimoghaddam H, M Galavi, A Ghanbari and N Panjehkeh. 2011. Salinity effects on seed germination and seedling growth of bread wheat cultivars. Trakia J Sci 9: 43-50.

Akhtar J, K Mahmood, KA Malik, S Ahmad and R Murray. 2003. Amelioration of saline-sodic soil through cultivation of a salt-tolerant kallar grass Leptochloa fusca. Environ Conserv 30: 168-174.

Al-Karaki GN. 2000. Growth, water use efficiency and sodium and potassium acquisition by tomato cultivars grown under salt stress. J Plant Nutr 23: 18. doi: https://doi.org/10.1080/01904160009381992.

Amran MB, NKE Sari, DA Setyorini, Y Wahyu, D Widiani and D Irnameria. 2015. Analisis kualitas tanah pantai Sawarna Kabupaten Lebak Provinsi Banten. Prosiding Simposium Nasional Inovasi dan Pembelajaran Sains. (SNIPS 2015) 8 dan 9 Juni 2015, Bandung, Indonesia, pp. 649-652. (in Indonesian).

Await P. 2009. Soil fertility management source. Afghanistan Water, Agriculture and Technology Transfer (AWATT) Project, 150p.

Banyo YE, AS Nio, P Siahaan and AM Tangapo. 2013. Konsentrasi klorofil daun padi pada saat kekurangan air yang diinduksi dengan polietilen glikol. J Ilmiah Sains 13: 1-8 https://doi.org/10.35799/ jis.13.1.2013.1615

Bray RH and LT Kurtz. 1945. Determination of total organic and available forms of phosphorus in soils. Soil Sci 59: 39-45. http://dx.doi.org/10.1097/00010694194501000-00006.

Bremner JM. 1996. Nitrogen-total. In: L Sparks, AL Page, PA Helmke, RH Loeppert, PN Soltanpour, MA Tabatabai, CT Johnston and ME Sumner (eds). 
Methods of Soil Analysis. Part 3 Chemical Methods. Soil Sci Am Soc Agron. SSSA (5), pp. 1085-1121.

Central Statistics Agency. 2020. Luas panen, produksi, dan produktivitas padi menurut provinsi 2018-2019. Badan Pusat Statistik: https://www.bps.go.id/ subject/53/tanamanpangan.html\#subjekViewTab.

Dewadaru DP and S Saputro. 2014. Kajian morfologi pantai di pantai slamaran Kabupaten Pekalongan Semarang: JOceanography 3: 105-123.

Dewi AK and MR Setiawati. 2018. Pengaruh pupuk hayati endofitik dengan Azolla pinnata terhadap serapan $\mathrm{n}$, n-total tanah, dan bobot kering tanaman padi (Oryza sativa L.) pada tanah salin. Agrologia 6: 5460. https://doi.org/10.30598/a.v6i2.168

Djuwansah M. 2013. Status natrium pada tanah tercemar limbah Industri tekstil di Rancaekek, Kabupaten Bandung. J Tanah dan Iklim 37: 25-34. (in Indonesian).

Dodd K, CN Guppy and PV Lockwood. 2010. Overcoming the confounding effects of salinity on sodic Soil Research. Commun Soil Sci Plan Anal 41: 22112219. https://doi.org/10.1080/00103624. 2010.504801.

Firmansyah E, B Kurniasih and D Indradewa. 2016. Respon varietas padi tahan salin terhadap beberapa durasi genangan dengan tingkat salinitas berbeda. Artikel Ilmiah 1: 50-62. (in Indonesian).

Follett RH, LS Murphy and RL Donahue. 1981. Fertilizers and soil amendments. Prentice-Hall, Inc, 557.

Gopalakrishnan T and L Kumar. 2020. Modeling and mapping of soil salinity and its impact on paddy lands in Jaffna Peninsula, Sri Lanka. Sustainability 12: 8317. https://doi.org/10.3390/su12208317

Grattan SR and CM Grieve. 1999. Mineral nutrient acquisition and response by plants grown in saline environments. In: M Pessarakli (ed). Handbook of Plant and Crop Stress. Marcel Dekker, Inc. New York, pp. 203-226.

Gupta S and S Sharma. 1990. Response of crops to high exchangeable sodium percentage. Irrig Sci 11:173179.

Habibi N. 2018. Respon Pertumbuhan dan Biomassa Galur-Galur Padi (Oryza sativa L.) Tahan salin. Master Tesis. Institut Teknologi Sepuluh November. (in Indonesian).

Hardjowigeno S. 2010. Ilmu Tanah. Akademia Pressindo, Jakarta. (in Indonesian).

Hasmunir H. 2017. Materi pembelajaran geomorfologi untuk program studi pendidikan geografi. $J$ Pendidik Geosfer 2: 9-21. (In Indonesian)

Irman, WA Nurgayah and N Irawati. 2017. Hubungan klorofil-a kaitannya dengan parameter fisika kimia di perairan Desa Tanjung Tiram Kecamatan Moramo Utara Kabupaten Konawe Selatan. J Sapa Laut 2: 97-102. (in Indonesian).

Jalil M, H Sakdiah, E Deviana and IG Subiksa. 2016. Pertumbuhan dan produksi beberapa varietas padi (Oryza sativa L.) pada berbagai tingkat salinitas. $J$ Agrotek Lestari 2: 63-74. (in Indonesian).
Kementrian Pertanian. 2019. Data lima tahun terakhir produksi dan luas panen padi. Kementerian Pertanian Republik Indonesia, Jakarta. (in Indonesian).

Kolinug KH, MA Langi, SP Ratag and W Nurmawan. Zonasi tumbuhan utama penyusun mangrove berdasarkan tingkat salinitas air laut di Desa Teling Kecamatan Tombariri. J Cocos 5: 1-9. (in Indonesian).

Leghari SJ, NA Wahocho, GM Laghari, A HafeezLaghari, G MustafaBhabhan, K HussainTalpur, TA Bhutto, SA Wahocho and AA Lashari. 2016. Role of nitrogen for plant growth and development: a review 11. $A d v$ Environ Biol 10: 209-218.

Manchanda G and N Garg. 2008. Salinity and its effects on the functional biology of legumes. Acta Physiol Plant 30: 595-618.

Mardiansyah, T Palupi and Maulidi. 2018. Respon Beberapa Varietas Padi Lokal Terhadap Cekaman Salinitas Pada Fase Pembibitan. J Sains Mahasiswa Pertanian 7: 1-9

Marsoedi D, J Dai, N Suharta, S Darul, S Hardjowigeno, J Hof and E Jordens. 1997. Guidelines for Landform Classification. Bogor: Pusat Penelitian Tanah dan Agroklimat, 9. (in Indonesian).

Marwanto, S., Rachman, A., Erfandi, D., 2009. Tingkat Salinitas Tanah Pada Lahan Sawah Intensif di Kabupaten Indramayu, Jawa Barat. Balai Penelitian Tanah, Balitbangtan, Kementerian Pertanian, pp. 175-190. (in Indonesian).

Morton JD, CG Roach, MJ Tong and AHC Roberts. 2004. Potassium in soil and pasture and leaching of cations on an allophanic soil in New Zealand. New Zealand J. Agric Res 47: 147-154. https://doi.org/ 10.1080/00288233.2004.9513582

Muliawan NRE, J Sampurno and MI Jumarang. 2016. Identifikasi nilai salinitas pada lahan pertanian di daerah jungkat berdasarkan metode daya hantar listrik (DHL). J Prisma Fisika 4: 69-72.

Nasrudin N and B Kurniasih. 2018. Growth and yield of inpari 29 rice varieties on raised-bed and different depths of sunken-bed in saline field. J Ilmu Pertan (Agric Sci) 3: 135-145.

Netondo, G.W., Onyango, J.C., Beck, E., 2004. Sorghum and salinity: I. Response of growth, water relations, and ion accumulation to $\mathrm{NaCl}$ salinity. Crop Sci 44: 797-805.

Pennock D and T Yates. 2006. Soil Sampling Design. In: MR Carter and EG Gregorich (eds). Soil Sampling and Methods of Analysis. Canadian Society of Soil Science, Canada. 1262p.

Pratama JA and AL Nikmati. 2015. Analisis kandungan chlorophyll gandasuli (Hedychium gardnerianum Shephard ex KerGawl) pada tiga daerah perkembangan daun yang berbeda. In: Prosiding Seminar Nasional Konservasi dan Pemanfaatan Sumberdaya Alam. Pendidikan Biologi, Pendidikan Geografi, Pendidikan Sains, PKLH - FKIPUNS. (in Indonesian). 
Putra AN and I Nita. 2020. Reliability of using highresolution aerial photography (red, green, and blue bands) for detecting available soil water in agricultural land. J Degrade Min Land Manage 7: 2221-2232.

Rachman A, A Dariah and S Sutono. 2018. Pengelolaan sawah salin berkadar garam tinggi. IAARD Press, Jakarta. (in Indonesian).

Rayes ML. 2007. Metode Inventarisasi sumber daya lahan. Andi, Yogyakakarta. (in Indoneisan).

Rhoades J, N Manteghi, P Shouse and W Alves. 1989. Soil electrical conductivity and soil salinity: new formulations and calibrations. Soil Sci Soc Am J 53: 433-439.

Robbins CW. 1984. Sodium adsorption ratio-exchangeable sodium percentage relationships in A high potassium saline-sodic soil. Irr Sci 5: 173-179.

Royston P. 1992. Approximating the shapiro-wilk w-test for non-normality. Stat Comput 2: 117-119.

Salama YA, MK Nagwa, SA Hassan, Saleh and MF Zaki. 2012. Zinc amelioration effects on plant growth and production under saline water irrigation conditions. J Appl Sci Res 8: 5877-5885.

Setiawan EB and R Herdianto. 2018. Penggunaan smartphone android sebagai alat analisis kebutuhan kandungan nitrogen pada tanaman padi. J Nasional Teknik Elektro dan Teknologi Informasi. 7: 273280. (in Indonesian).

Shrivastava P and R Kumar. 2015. Soil salinity: A Serious environmental issue and plant growth promoting bacteria as one of the tools for its alleviation. Saudi J Biol Sci 22: 123-131. https://doi.org/10.1016/ j.sjbs.2014.12.001

Sipayung R. 2003. Stres garam dan mekanisme toleransi tanaman. USU Digit. Libr. 1-7. (in Indonesian).
Sitorus T. 2012. Analisis salinitas dan dampaknya terhadap produktivitas padi di wilayah Pesisir Indramayu. Skripsi. FMIPA IPB, Bogor. (in Indonesian).

Soussi M. 1998. Effects of salt stress on growth, photosynthesis and nitrogen fixation in chick-pea (Cicer Arietinum L.) 9. J Exp Bot 49: 1329-1337.

Soil Survey Staff. 2014. Keys to Soil Taxonomy, Twelfth Edition. Natural Resources Conservation Services, United States Department of Agriculture.

Suhartini T and T Zulchi. 2018. Toleransi plasma nutfah padi lokal terhadap salinitas. Buletin Plasma Nutfah 23: 51-58. https://doi.org/10.21082/blpn.v23n1. 2017.p51-58.

Vadas P, A Mallarino and A McFarland. 2006. The importance of sampling depth when testing soils for their potential to supply phosphorus to surface runoff. Ext. Fact Sheets 1.

Wahyuningsih S, A Kristiono and A Taufiq. 2017. Pengaruh jenis amelioran terhadap pertumbuhan dan hasil kacang hijau di tanah salin. Buletin Palawija 15: 69-77.

World Agricultural Production. 2020. Production rice world. In http:/www.worldagriculturalproduction.com/ crops/rice.aspx. Verified Oktober, 032020

Wulan TR, W Ambarwulan, E Siswanti and E Maulana. 2016. Variasi kondisi air tanah sebagian pesisir kabupaten rembang kaitannya dengan bentuk lahan. Prosiding Seminar Nasional Kelautan. Universitas Trunojoyo Madura, 27 Juli 2016, pp. 173-179.

Zakiyah ZN, C Rahmawati and I Fatimah. 2018. Analysis of phosphorus and potassium levels in organic fertilizer in the Integrated Laboratory of Jombang District. Indonesian J Chem Res 3: 38-48. 